\title{
DINAMIKA HUBUNGAN ANTAR AGAMA DAN MASYARAKAT ${ }^{1}$
}

\author{
MARTINUS DURYADI ${ }^{2}$
}

\begin{abstract}
This paper describes the dynamics of the relationship between religion and society in the minds of scientists. Charles Darwin saw religion as a system of symbols which continue to evolve from the simplest stage to forms more complex. The evolution of religion is an attempt to build a new understanding with regard to the context which is also new. Emile Durkheim viewed religion also has a social function is to maintain the unity of the community. Religion was able to build a collective consciousness to raise social solidarity. Max Weber also viewed religion capable of forming a particular social status. He looked specifically Protestantism strongly supports the creation of community capitalism. Only Karl Marx saw religion as pessimistic. He saw religion as the opium of the people. For him religion only gives false answers. Often religion conserving system-the system that oppresses.
\end{abstract}

Kata-kata Kunci : Agama, Masyarakat, perilaku sosial, sistem simbol, kapitalisme

$1 \quad$ Disampaikan dalam acara Pendidikan dan Latihan: Kepemimpinan Yang Melayani di Gereja dan Masyarakat yang diselenggarakan oleh DepDik Sinode GIA dan STT Abdiel, tanggal 14-18 Januari 2008 di STT Abdiel, Ungaran

2 Pdt. Martinus Duryadi, M.Si. merupakan dosen STT Abdiel. Saat ini sebagai Sekretaris Dep Dik Sinode dan Gembala Sidang GIA Jemaat Manyaran, Semarang 


\section{PENDAHULUAN}

gama $^{3}$ dan manusia tidak dapat dipisahkan. Sejarah manusia adalah
merupakan sejarah agama. Dengan demikian maka hubungan manusia (masyarakat) dengan agama sudah terjadi sejak manusia ada. Bahan-bahan yang menjadi dasar untuk menggali sejarah umat manusia tidak dapat dilepaskan dari peninggalan-peninggalan sejarah yang senantiasa bersangkut-paut dengan agama. Atau dengan kata lain, kita dapat mengerti sejarah manusia melalui peninggalan-peninggalan baik yang berupa tulisan, lukisan maupun karya arsitektur keagamaan.

Sejarah manusia Indonesia dapat diketahui dari peninggalan-peninggalan bangunan yang ada hubungannya dengan agama. Sebagai bukti sejarah yang tidak dapat disangkal bahwa manusia Indonesia dalam perkembangan sejarahnya dibentuk oleh beraneka ragam agama karena didukung fakta adanya peninggalan bangunan-bangunan yang sangat erat dengan agama. Peninggalan baik berupa yoni, lingga atau candi merupakan salah satu bentuk karya dan bangunan keagamaan. Candi Gedong Songo, Candi Dieng, Candi Prambanan, Candi Penataran merupakan peninggalan bangunan keagamaan yang bercorak Hindu. Candi Borobudur merupakan peninggalan Budha. Masjid Demak merupakan peninggalan Islam. Gereja Blendug merupakan peninggan bangunan Kristen. Klenteng, peninggalan Kong Hu Chu dsb. Hal-hal tersebut yang terjadi di Indonesia, di belahan bumi lainnyapun kita juga dapat menemukan bagaimana relasi agama dan masyarakat dapat juga diketahui dari bangunan maupun peninggalan-peninggalan tempat ibadah suatu agama.

Hubungan antara agama dan masyarakat telah diperdebatkan secara hangat di dalam literatur sosiologi agama. Realitas ini, menyebabkan tidak mudah untuk memberikan paparan tentang dinamika hubungan agama dan masyarakat dalam waktu yang singkat dan terbatas. Oleh sebab itu, pendekatan yang dipakai untuk memaparkan hubungan agama dan masyarakat tidak dilakukan secara kronologis historis, tetapi lebih kepada fenomenologis. Maksudnya bahwa dinamika hubungan agama dan masyarakat yang disajikan adalah fenomenafenomena hubungan agama dan masyarakat dalam sejarah kehidupan umat manusia. Dalam dinamika hubungan agama dan masyarakat, kita akan mendapat

$3 \quad$ Agama yang dimaksud penulis dalam pengertian relegi, bukan agama sebagai sebuah difinisi politik seperti yang sekarang berkembang di Indonesia, yang dipahami secara dangkal 
berbagai macam hal. Pada suatu saat, agama dapat membawa pengaruh negatif bagi perkembangan masyarakat, namun dalam hal yang lain kita mendapatkan bahwa agama membawa dampak yang positif bagi kehidupan masyarakat. Pada pemaparan ini, kita akan mencoba melihat fenomena-fenomena yang terjadi dalam dinamika hubungan agama dan masyarakat.

\section{EVOLUSI AGAMA}

Istilah evolusi, telah menjadi istilah yang sangat familiar dalm kehidupan manusia. Istilah evolusi pertama kali disampaikan oleh Charles Darwin. Istilah dan konsep evolusi yang dilontarkan oleh Darwin menimbulkan kegemparan hebat, khususnya dalam kalangan umat beragama. Dalam teori evolusi Darwin, dijelaskan bahwa manusia merupakan hasil evolusi dari alam semesta. Dengan teori ini, maka keyakinan yang diajarkan oleh agama bahwa manusia diciptakan Tuhan mulai dipertanyakan. Akibatnya perdebatan kebenaran teori tersebut masih terjadi sampai saat ini.

Pada kesempatan ini, penulis tidak akan menguraikan teori Darwin, namun untuk melihat bagaimana dinamika hubungan agama dan manusia yang tidak terpisahkan dapat dilihat dari teori evolusi agama. Jangan curiga dan salah paham. Dalam evolusi agama ${ }^{4}$, yang akan dibicarakan dalam evolusi agama "bukan manusia yang beragama, dan juga bukan struktur situasi keberagamaan akhir dari manusia yang berevolusi melainkan agama sebagai sistem symbol" ${ }^{2}$.

Dalam evolusi agama yang akan kita bicarakan dibangun dan didasarkan pada beberapa anggapan dasar. Anggapan dasar tersebut adalah: Pertama, simbolisasi agama cenderung berubah sepanjang waktu, setidak-tidaknya dalam hal tertentu, dalam arah yang lebih berdiferensiasi, mendalam yang menuju kepada formulasi yang dirasionalkan. Kedua, konsepsi-konsepsi tindakan keagamaan dari sifat pelaku keagamaan, dari organisasi keagamaan dan dari tempat agama dalam masyarakat cenderung berubah dengan cara sistematis sesuai dengan perubahan-perubahan dalam symbol-simbol keagamaan. Ketiga,

$4 \quad$ Yang penulis maksud dengan evolusi adalah suatu proses meningkatnya diferensiasi dan kompleksitas organisasi yang memberi organisme, sistem sosial atau satuan apapun barangkali, dengan kemampuan beradaptasi lebih besar terhadap lingkunganya sehingga sistem tersebut secara relative lebih otonom terhadap lingkunganya dibandingkan sistem yang kurang kompleks pada masa nenek moyang, lihat R. N Bellah, Evolusi Agama, dalam Agama: Dalam Analisa dan Intrepretasi Sosiologis, Roland Robertson, Rajawali, Jakarta 1988, hal 304

5 R. N Bellah, Evolusi Agama, dalam Agama: Dalam Analisa dan Intrepretasi Sosiologis, Roland Robertson, Rajawali, Jakarta 1988, hal 305 
perubahan-perubahan dalam konteks agama berkaitan dengan berbagai dimensi lain perubahan dalam konteks sosial lain yang berhubungan dengan evolusi sosial budaya ${ }^{6}$.

Dalam pemahaman evolusi agama, agama berkembang dari fase yang sederhana menuju ke fase yang lebih kompleks. Fase-fase evolusi agama tersebut adalah : fase primitif, fase arkaik, fase historis, fase pra modern dan fase modern. Dalam fase-fase evolusi agama bagaimana hubungan agama dan masyarakat begitu nampak sangat jelas. Untuk lebih jelasnya perhatikan table yang berikut

Tabel evolusi agama ${ }^{7}$

\begin{tabular}{|c|c|c|}
\hline Fase & Sistem Simbol & Tindakan keagamaan \\
\hline Agama Primitif & $\begin{array}{l}\text { - le monde mythique, dreaming } \\
\text { - Memandang dunia secara } \\
\text { mistis } \\
\text { - Melalui mimpi, membentuk } \\
\text { simbolisme cult } \\
\text { - mite par excellence }\end{array}$ & $\begin{array}{c}\text { - Belum mengenal } \\
\text { penyembahan dan korban } \\
\text { - identifikasi dan partisipasi } \\
\text { diri lebih penting } \\
\text { - Ritual par excellence } \\
\text { - belum mengenal jabatan } \\
\text { iman/pendeta } \\
\text { - organisasi keagamaan tidak } \\
\text { terpisah dengan struktur } \\
\text { sosial (menyatu) } \\
\text { - usia lebih penting dalam } \\
\text { menentukan pembedaan } \\
\text { status sosial } \\
\text { - solidaritas masyarakat kuat }\end{array}$ \\
\hline Agama arkaik & $\begin{array}{c}\text { - mite mulai disistematisasi } \\
\text { - mengenal cult, dewa, imam, } \\
\text { persembahan, korban } \\
\text { - mahkluk-mahkluk mistis } \\
\text { digambarkan dengan sifat } \\
\text { yang jelas } \\
\text { - memandang dunia secara } \\
\text { monistik }\end{array}$ & $\begin{array}{l}\text { - mengenal cult, dimana } \\
\text { perbedaan manusia dan } \\
\text { tuhan lebih diperjelas } \\
\text { - mempraktekkan } \\
\text { persembahan dan korban } \\
\text { - Munculnya sistem dua } \\
\text { kelas: kelas penguasa } \\
\text { (agama) dan kelas rakyat }\end{array}$ \\
\hline
\end{tabular}

$6 \quad$ Ibid, hal 309

7 Tabel ini merupakan ringkasan pemikiran R. N. Bellah tentang evolusi agama, yang diambil dalam R. N Bellah, Evolusi Agama, dalam Agama: Dalam Analisa dan Intrepretasi Sosiologis, Roland Robertson, Rajawali, Jakarta 1988, hal 310-341 


\begin{tabular}{|c|c|c|}
\hline Agama Historis & $\begin{array}{c}\text { - masyarakat sudah } \\
\text { mengenal huruf/tulisan } \\
\text { - pemikiran secara } \\
\text { transenden, sehingga bersifat } \\
\text { dualistik } \\
\text { - Terjadi proses } \\
\text { demitologisasi terhadap } \\
\text { agama arkaik } \\
\text { - mulai memandang tuhan } \\
\text { secara monoteis }\end{array}$ & $\begin{array}{c}\text { - mengajarkan tindakan } \\
\text { untuk mendapatkan } \\
\text { keselamatan } \\
\text { - hidup terpisah dari dunia } \\
\text {-Munculnya organisasi } \\
\text { keagamaan } \\
\text { - munculnya elit agama } \\
\text { dalam masyarakat } \\
\text { - timbulnya ketegangan dan } \\
\text { konflik sosial }\end{array}$ \\
\hline $\begin{array}{c}\text { Agama } \\
\text { pramodern }\end{array}$ & $\begin{array}{c}\text { - lenyapnya hirarkis yang } \\
\text { menstrukturkan dunia dan } \\
\text { akhirat } \\
\text { - keselamatan tidak } \\
\text { diperoleh dengan menarik } \\
\text { diri dari dunia, tetapi justru } \\
\text { keterlibatan dengan dunia } \\
\text { - hubungan langsung antara } \\
\text { individu dan kenyataan } \\
\text { transcendental }\end{array}$ & $\begin{array}{c}\text { - tindakan keagamaan } \\
\text { identik dengan keseluruhan } \\
\text { kehidupan } \\
\text { - tekanan pada keyakinan, } \\
\text { kualitas internal ketimbang } \\
\text { tindakan religius } \\
\text { - menolak otoritas penguasa } \\
\text { agama } \\
\text { - manusia dibedakan dengan } \\
\text { orang terpilih dan tak terpilih }\end{array}$ \\
\hline Agama modern & $\begin{array}{c}\text { - ditandai dengan kemajuan } \\
\text { intelektual } \\
\text { - tidak ada ruang untuk } \\
\text { sistem symbol agama yang } \\
\text { dualistik } \\
\text { - Simbolisasi hubungan } \\
\text { manusia dengan kondisi- } \\
\text { kondisi akhir keberadaannya } \\
\text { tidak menjadi monopoli } \\
\text { kelompok tertentu }\end{array}$ & $\begin{array}{c}\text { - manusia tidak lagi } \\
\text { menyandarkan diri pada } \\
\text { lembaga keagamaan untuk } \\
\text { mendapatkan keselamatan } \\
\text { - tindakan sosial selalu } \\
\text { dihubungkan dengan usaha } \\
\text { untuk memenuhi kebutuhan } \\
\text { - sering munculnya } \\
\text { kelompok-kelompok yang } \\
\text { sangat terbuka, tetapi juga } \\
\text { mudah bubar } \\
\text { - kebudayaan dan } \\
\text { kepribadian dianggap } \\
\text { mampu memperbaiki diri } \\
\text { sendiri }\end{array}$ \\
\hline
\end{tabular}

\section{DIMENSI-DIMENSI KEBERAGAMAAN ${ }^{8}$}

Agama dan manusia tidak dapat dipisahkan dan berdiri sendiri-sendiri. Dalam evolusi agama yang baru saja kita bahas, kita melihat bahwa agama

$8 \quad$ Untuk lebih jelasnya silahkan baca R. Stark dan C. Y Glock, Dimensi-dimensi Keberagamaan, dalam Agama Dalam Analisa dan Intrepretasi Sosiologis, Roland Robertson, Rajawali, Jakarta 1988, hal 291301 
menjadi 'hidup dan dinamis' karena ada manusia yang senantiasa melakukan usaha untuk memberi pemahaman baru terhadap simbol-simbol agama sehingga menghasilkan tindakan agama yang lebih sesuai dengan kondisi dan situasi lingkungan. Memang kadangkala kita mengalami kesulitan untuk memahami tindakan keagamaan seseorang; karena kita tidak mencoba memahami tindakan tersebut dari dimensi keberagamaan yang bersangkutan tetapi dari dimensi kita. Oleh sebab itu, saya merasa perlu untuk membicarakan dimensi keberagaaman dalam tulisan ini.

Menurut R. Stark dan C. Y. Glock, dimensi keberagamaan dibedakan menjadi lima yaitu: Pertama, dimensi keyakinan. Dimensi ini berisikan pengharapanpengharapan dimana orang yang religius berpegang teguh pada pandangan teologis tertentu, mengakui kebenaran doktrin-diktrin tersebut. Setiap agama mempertahankan seperangkat kepercayaan dimana para penganutnya diharapkan akan taat. Ruang lingkup isi keyakinan itu bervariasi tidak hanya diantara agama-agama, tetapi juga diantara tradisi-tradisi dalam agama.

Kedua, dimensi praktek agama. Dimensi ini mencakup perilaku pemujaan, ketaatan dan hal-hal yang dilakukan orang untuk menunjukkan komitmen terhadap agama yang dianutnya. Praktek keagamaan tersebut mecakup dalam hal ritual dan ketaatan. Praktek ritual mengacu pada seperangkat ritus, tindakan keagamaan formal dan praktek-praktek suci yang semua agama mengharapkan para penganutnya melaksanakannya. Tindakan ritual tersebut harus dilaksanakan dengan ketaatan.

Ketiga, dimensi pengalaman. Dalam dimensi ini, seseorang akan mengalami pengalaman keagamaan berupa perasaan-perasaan, persepsi-persepsi dan sensasi-sensasi yang dialami seorang pelaku atau kelompok keagamaan dengan Tuhan, kenyataan terakhir dan otoritas transendental. Melalui pengalaman keagamaan ini, menjadi tanda keberagamaan individu

Keempat, dimensi pengetahuan agama. Dimensi ini mengacu kepada harapan bahwa orang-orang yang beragama paling tidak memiliki sejumlah minimal pengetahuan mengenai dasar-dasar keyakinan, ritus-ritus, kitab suci dan tradisi-tradisi. Pengetahuan berkaitan erat dengan keyakian, tetapi meskipun sangat berkaitan erat keyakian tidak perlu diikuti pengetahuan, demikian juga sebaliknya pengetahuan tidak bersandar pada keyakinan. Karena seseorang dapat memiliki keyakinan yang kuat tanpa benar-benar memahami agamanya. 
Kelima, dimensi konsekuensi. Dimensi ini mengacu pada identifikasi akibatakibat keyakinan keagamaan, praktek, pengalaman dan pengetahuan seseorang dari hari ke hari. Dimensi-dimensi keberagamaan empat terdahulu sangat berpengaruh besar terhadap dimensi konsekuensi keberagamaan seseorang. Dimensi konsekuensi nampak nyata dalam perilaku-perilaku individu maupun perilaku sosial masyarakat.

\section{FUNGSI AGAMA DALAM MASYARAKAT}

Menyatunya agama dan masyarakat, menyebabkan agama menjadi bagian integral dari kebudayaan manusia. Tidak dapat kita sangkal bahwa agama memainkan peran yang vital dalam hidup manusia. Agama mengatur hubungan manusia dangan tuhannya, hubungan manusia dengan manusia lainnya, dan hubungan antara manusia dengan lingkungannya baik alam, sosial budaya maupun kerohanian. Berbagai usaha telah dilakukan untuk menemukan jawaban mengapa agama begitu kuat pengaruhnya dalam kehidupan manusia. Pada kesempatan ini, kajian kita menggunakan kacamata sosiologi. Dalam kajian sosiologi ini, kita akan menaruh perhatian pada fungsi agama dalam masyarakat. Istilah fungsi menunjuk kepada sumbangan yang diberikan agama, atau lembaga sosial lainya untuk mempertahankan keutuhan masyarakat dalam bentuk usaha yang aktif dan berjalan terus menerus. Dengan demikian perhatian kita adalah peranan yang telah dan masih dimainkan oleh agama dalam rangka mempertahankan kelangsungan hidup masyarakat-masyarakat tersebut.

Manusia, disamping sebagai mahkluk religius, juga mahkluk sosial. Sebagai mahkluk sosial, manusia hidup bersama dengan yang lain. Tanpa yang lain, manusia terasa lemah; namun yang lainpun tidak selamanya menjadi penolong, kadang juga menimbulkan berbagai macam masalah sehingga terjadi konflik. Berbagai macam masalah yang dihadapi manusia, bukan hanya karena relasi sosial yang mengalami hambatan, tetapi juga disebabkan oleh 'kelemahan bawaan' manusia. Kelemahan bawaan manusia tersebut adalah : (1) Eksistensi manusia ditandai oleh rasa ketidakpastian dalam menghadapi alam. (2) kemampuan manusia untuk mengendalikan alam sangat terbatas sehingga timbul konflik antara keinginan dan ketidakberdayaan. (3) manusia mahkluk sosial dengan segala alokasi kelangkaan fasilitas yang menyebabkan perbedaan 
distribusi barang, nilai dan norma hidupnya9. Dalam kondisi yang demikianlah fungsi agama dalam masyarakat mendapat tempat yang strategis. Mengapa fungsi agama begitu penting? Karena agama dapat menjawab berbagai pergumulan hidup umat manusia dalam relasi dengan Tuhan, sesama manusia maupun lingkungannya. Fungsi yang dimainkan agama tersebut adalah:

Agama menyajikan dukungan moral sarana emosional, pelipur di saat manusia mengahdapi ketidakpastian dan frustasi.

Agama menyajikan sarana hubungan transendental melalui amal ibadat, yang menimbulkan rasa damai dan identitas baru yang menyegarkan

Agama mengesahkan, memperkuat, memberi legitimasi dan mensucikan nilai dan norma masyarakat yang telah mapan dan membantu mengendalikan ketentraman, ketertiban dan stabilitas masyarakat

Agama memberikan standart nilai untuk mengkaji ulang nilainilai dan norma-norma yang telah mapan.

Agama memberikan rasa identitas diri

Agama memberikan status baru dalam pertumbuhan dan siklus perkembangan individu melalui berbagai krisis ${ }^{10}$.

Sebagaimana yang telah dipaparkan di atas, bukan berarti agama menjadi jawaban atas segala problem dan persoalan manusia. Agama seperti obat, bila salah menggunakan akan menjadi racun yang mematikan, tetapi apabila dengan tetap digunakan memang akan menjadi obat yang menyembuhkan. Hal tersebut seperti yang dikatakan oleh Abdul Karim Soroush, seorang cendikiawan muslim liberal Iran. Dalam tulisannya, Soroush mengatakan bahwa: "akan tetapi obat yang dianggap manjur itu justru memperparah rasa sakit, ... jika anda sungguh bertempat di dekat mata air kehidupan tersebut, mengapa ada begitu banyak bibir yang kehausan, mengapa banyak kaum papa tertidur di atas 'harta' itu tanpa mampu merasakan manfaatnya ${ }^{11}$ Dari paparan tersebut di atas, kita melihat bahwa agama di satu sisi menampilkan diri dengan fungsi yang positif bagi kehidupan masyarakat, namun di sisi yang lain agama menampilkan juga

9 Djamari, Agama Dalam Perspektif Sosiologi, Alfabeta, Bandung, 1993, hal 84

10 Ibid hal 85

11 Abdul Karim Soroush, Menggugat Otoritas dan Tradisi Agama, Mizan, Bandung, 2002, hal 38 
fungsi yang positif. Penampilan agama dalam berbagai sisi tersebut, kemudian oleh para peneliti menemukan beberapa teori tentang fungsi agama dalam masyarakat. Beberapa teori tentang fungsi agama dalam masyarakat tersebut adalah:

\section{TEORI KONFLIK SOSIAL}

Teori konflik sosial diajarkan oleh Karl Marx. Marx lahir pada tanggal 5 Mei 1818, anak seorang pengacara Yahudi. Kedua kakenya, baik dari ibu maupun ayahnya adalah seorang rabi. Tetapi karena penguasa sangat anti Yahudi, maka ayah Marx terpaksa pindah menjadi Kristen. Mark sangat dipengaruhi oleh Hegel. Pemikiran Mark sangat dipengaruhi oleh konsep pemikiran bahwa : (1) realitas ekonomi menentukan perilaku manusia (2) sejarah manusia adalah cerita perjuangan klas, kancah konflik terus menerus di setiap masyarakat antara orang-orang yang memiliki benda, biasanya orang kaya dengan orang-orang yang harus bekerja untuk hidup terus, biasanya orang miskin ${ }^{12}$.

Marx banyak memberikan kritik terhadap kehidupan sosial, termasuk juga dalam kehidupan agama. Pemikiran Marx dalam bidang agama dipicu oleh pemikiran Ludwig Feuerbach, bahwa Tuhan adalah ide ciptaan manusia. Dalam pemikiran Feurbach dikatakan bahwa agama " berbicara tentang suatu wujud yang asing - tentang Tuhan atau yang mutlak - ... semua sifat personal yang paling kita kagumi- ideal seperti kebaikan, keindahan, keadaan sebenarnya, hikmah, cinta, ketabahan, dan kuatnya karakternya- lalu mencopot sifat-sifat itu dari manusia dan memproyeksikannya ke tabir langit dimana mereka disembah.... Nama suatu wujud supernatural yang disebut Tuhan ${ }^{13}$. Berangkat dari pemikiran Feurbach ini, Marx mengatakan bahwa agama menyebabkan manusia terasing dari dirinya. Keterasingan ini disebabkan karena agama telah mengambil sifat-sifat -ideal moral- dari kehidupan manusia yang dasar dan secara tidak wajar memberikannya pada suatu wujud asing dan khayal yang disebut Tuhan ${ }^{14}$.

Dalam pemikiran Marx lebih lanjut tentang agama mengatakan bahwa: Penderitaan agama pada saat yang sama merupakan ekspresi penderitaan

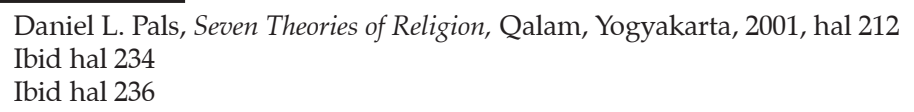


ekonomi yang riil dan protes melawan penderitaan yang riil. Agama adalah keluh kesah mahkluk yang tertindas, hati dunia yang tak berhati, sebagaimana ia adalah roh dari suatu keadaan yang tak mempunyai roh. Ia adalah opium bagi masyarakat ${ }^{15}$. Dari penjelasan tersebut, menurut Marx agama tidak memiliki fungsi yang membangun dalam masyarakat. Agama justru menimbulkan masalah, sebab agama hanya memberi kebahagian dan penyelesaian masalah secara semu sepertiopium (candu, narkoba). Karenaitu agama perlu dihapuskan. Dalam penjelasannya lebih lanjut Marx mengatakan "penghapusan agama karena dianggap kebahagiaan yang ilusi'16.

Praktek kolonialisme dan imperialisme yang dilakukan oleh Negara-negara yang beragama, khususnya Kristen pada masa Marx, menyebabkan penolakan Marx terhadap agama semakin menguat. Menurut Marx, fungsi sosial agama Kristen tidak menciptakan kehidupan sosial yang lebih baik, justru sangat buruk. Menurut Marx fungsi sosial agama Kristen yang memperburuk kehidupan sosial tersebut adalah:

Membenarkan perbudakan zaman kuno, mengagungkan pembelian budak di abad pertengahan dan sama-sama mengetahui, saat perlu bagaimana mempertahankan penindasan kaum proletariat, meskipun mereka memandang sedih atas hal itu.

Mengajarkan perlunya suatu klas penguasa dan suatu klas yang tertindas, dan semua yang diajarkan kepada yang terakhir ini adalah harapan yang saleh bahwa yang pertama ini akan bermurah hati

Menyatakan bahwa semua perbuatan jahat dari para penindas terhadap orang-orang yang tertindas adalah merupakan suatu hukuman yang adil terhadap dosa asal dan dosa-dosa yang lain ataupun pencobaan yang dijatuhkan Tuhan Yesus di dalam hikmahNya yang terbatas kepada orang-orang yang ditebus.

Mengajarkan perasaan pengecut, penghinaan diri, kerendahan diri, ketundukan dan kepatahan hati ${ }^{17}$

Perjuangan Marx dalam bidang ekonomi dan keadilan telah menyebabkan Marx melihat agama secara negatif. Wajah agama yang dilihat oleh Marx

\footnotetext{
$15 \quad$ Ibid hal 237

16 Ibid

17 Ibid hal 239-240
} 
adalah wajah agama yang negatif. Agama yang dilihat oleh Marx adalah agama yang tidak peduli dan memperhatikan lingkungan sosial sekitarnya. Dalam perkembangan selanjutnya, ternyata kaum Marxis tidak lagi melihat agama secara negatif, misalnya para tokoh teologia pembebasan, agama dan teologi telah menjadi gerakan melawan dan protes terhadap ketidakadilan dalam masyarakat. Agama menampilkan diri dalam sisi negatif karena agama telah dimanfaatkan para penguasa untuk kepentingan klas penguasa. Agama telah dipolitisir. Saat inipun, kita juga dapat melihat agama yang menakutkan dan garang, bila agama telah dipenuhi oleh kepentingan kekuasan kelompok elit agama/penguasa tertentu.

\section{TEORI KESADARAN KOLEKTIF ATAU SOLIDARITAS SOSIAL}

Emile Durkheim lahir pada tahun 1858 di kota Epinal, Prancis. Ayahnya seorang rabi sedangkan masa sekolahnya sangat terpengaruh oleh gurunya seorang Roma Katholik. Durkheim merupakah bapak sosiologi modern. Setelah melakukan banyak penelitian dan tulisan dalam bidang sosiologi, akhirnya Durkheim tertarik juga dalam bidang agama. Durkheim akhirnya tertarik terhadap peran agama dalam kehidupan sosial. Penelitian dalam bidang ini menghasilkan buku The Elementary Forms Of the Religious Life (1912).

Sumbangan Durkheim dalam bidang sosiologi agama adalah teorinya tentang fungsi agama dalam masyarakat. Menurut Durkheim, agama berfungsi memelihara kesatuan sosial. Menurut Durkheim, di balik keanekaragaman ritual, symbol dan kepercayaan agama terdapat karakteristik yang mendasari semua agama, sehingga yang membentuk masyarakat adalah jiwa agama. Menurut Durkheim, dalam hidup manusia, dibedakan antara yang profane dan yang sakral. Yang sakral menurut Durkheim selalu dianggap superior, sangat kuasa, terlarang dari hubungan normal, dan pantas mendapat penghormatan tinggi. Hal-hal yang profan adalah sebaliknya; bersifat biasa, tak menarik dan merupakan kebiasaan praktis kehidupan sehari-hari ${ }^{18}$. Agama dalam sistem sosial masyarakat termasuk dalam kawasan sakral. Dalam penjelasan lebih lanjut Durkheim mengatakan bahwa agama adalah sebuah sistem terpadu dari kepercayaan dan praktik yang berhubungan dengan hal-hal yang sakral, yakni hal-hal yang terpisah dan terlarang ${ }^{19}$.

18 Daniel L. Pals, Seven Theories of Religion, Qalam, Yogyakarta, 2001, hal 167

19 Ibid 
Agama menurut Durkheim bukan masalah pribadi, tetapi masalah sosial. Meskipun sebagai individu manusia membuat pilihan dalam diri kita, namun kita melakukannya dalam kerangka sosial yang diberikan pada kita sejak lahir. Kita berbicara dengan bahasa yang tidak kita buat, kita memakai instrument yang tidak kita temukan, perbendaharaan pengetahuan dipindahkan pada setiap generasi ${ }^{20}$. Dalam semua kebudayaan, agama adalah bagian yang paling berharga dari perbendaharaan sosial. Agama melayani masyarakat dengan menyediakan sejak pertumbuhan berupa ide, ritual, sentimen yang membimbing kehidupan setiap orang yang ada di dalamnya ${ }^{21}$.

Agama dalam pandangan Durkheim, mempunyai kekuatan untuk membangun kesadaran kolektif. Dalam agama, tiap-tiap individu terikat dengan kesadaran kolektif yang terus bertumbuh dan membentuk solidaritas sosial. Jika agama dapat membangkitkan dan menumbuhkan kesadaran kolektif, maka masyarakat tidak pernah akan hilang/musnah. Yang perlu kita lakukan saat ini, adalah bagaimana agama dapat terus membangkitkan dan melahirkan kesadaran kolektif di tengahtengah kehidupan sosial. Tugas ini tidak mudah, tetapi juga bukan hal yang sulit; artinya dapat dilakukan apabila agama didudukkan pada tempatnya.

\section{TEORI MAKNA DALAM KEHIDUPAN SOSIAL}

Teori ini dikemukankan oleh Max Weber. Weber seorang ilmuwan sosiologi dan ekonomi politik, lahir pada tahun 1864. Karya agung Weber yang menjelaskan bagaimana peran agama dalam kehidupan sosial ekonomi, yang sangat terkenal yaitu Etika Protestan dan Semangat Kapitalisme. Pada mulanya karya ini terbit sebagai artikel, yang diterbitkan pada tahun 1904 dan 1905. Penelitian Weber didasarkan fakta di barat pada zamannya. Weber melihat bahwa agama sangat memberi pengaruh pada status sosial dalam peradaban dan kehidupan manusia. Dari penelitian Weber tersebut disimpulkan bahwa " para pemimpin bisnis dan pemilik modal maupun para karyawan perusahaan yang mempunyai kemampuan (skill) tinggi ataupun para staf terdidik, baik secara tehnis maupun komersial ternyata kebanyakan adalah orang protestan ${ }^{22}$. Dari kenyatan ini, maka Weber mencoba mencari jawabannya dari faktor agama.

\footnotetext{
$20 \quad$ Ibid hal 188

21 Ibid hal 189

22 Max Weber . Etika Protestan dan Semangat Kapitalisme, Pustaka Promethea, Surabaya, 2000, hal 35
} 
Dalam penelitian lebih lanjut, Weber menyimpulkan bahwa jika para pebisnis, para staf yang berpengaruh adalah-orang-orang protestan, hal tersebut bukan kebetulan, tetapi disebabkan oleh faktor protestan. Weber mencoba mencari jawaban dengan menggali faktor-faktor penting dari protestan yang mempengaruhi perilaku sosial dan kedudukan sosial. Lebih lanjut Weber mengatakan bahwa dalam protestanisme terdapat potensi transformatif yang dapat mendorong perkembangan peranan-peranan baru dalam tiga arah yaitu : Pertama, peranan-peranan tertentu yang baru dengan tujuan yang baru, kedua, berkembangnya institusi organisasi dan hukum yang lebih luas, ketiga, berkembangnya tipe-tipe motivasi yang baru ${ }^{23}$.

Konsep penting dalam ajaran Protestan yang begitu kuat mempengaruhi perilaku sosial, dapat dijelaskan sebagai berikut:

Dalam teologia Kristen, ajaran bahwa orange percaya adalah umat pilihan .

Sebagai umat pilihan, maka ia harus hidup berbeda dengan umat yang bukan pilihan, bukan hanya dalam hal ke gereja, tetapi juga kehidupan sehari-hari, karena mereka sangat menekankan askese.

Bekerja, adalah bentuk ibadah/pelayanan kepada Allah, maka harus dilakukan dengan sungguh-sungguh dan sepenuh hati

Konsep Weber tentang fungsi agama dalam memberi makna hidup manusia , memang sering dipertanyakan kevalidannya, tetapi banyak juga yang menerima pemikiran tersebut dan dijadikan sebagai landasan teori dalam melakukan pengkajian terhadap hubungan agama dalam pemberian makna kehidupan sosial. Di Indonesia, seorang pemikir Islam, yaitu Mohamad Sobary mencoba menggunakan teori Weber dalam melakukan pengkajian kehidupan masyarakat Islam di komunitas Suralaya, Betawi ( lihat Resensi bukunya)

\section{Kesimpulan}

Dari uraian yang telah dipaparkan ada beberapa pokok-pokok yang perlu diperhatikan yaitu:

23 S.N Eisenstadt, Tesis Mengenai Etika Protestan, Dalam Agama: Dalam Analisa dan Intrepretasi Sosiologis, Roland Robertson, Rajawali, Jakarta 1988, hal 367 
Bahwa manusia dan agama tidak dapat dilepaskan, dan mereka senantiasa bersangkut paut.

Penggunaan simbol-simbol agama dalam masyarakat mengalami perkembangan dari bentuk yang sederhana, menuju yang kompleks, dan relasi manusia dengan symbol-simbol keagamanya juga mengalami perubahan.

Peran pemimpin agama dalam evolusi agama juga mengalami perubahan, dalam agama primitif, arkaik dan historis peran pemimpin agama sangat kuat, sehingga umat sangat tergantung pada pemimpin, tetapi dalam agama pra modern dan modern peran pemimpin mulai berkurang dan kemandirian serta kedewasaan umat semakin besar.

Pemahaman umat terhadap dimensi keagamaan sangat berpengaruh terhadap perilaku dan sikap sosial umat.

Agama dapat memberi pengaruh yang negatif bagi kehidupan sosial umat, dari bentuk yang sangat tertutup (eklusif) sampai dalam bentuk radikal yang anarkis, apabila agama dipolitisir untuk kepentingan elit penguasa tertentu.

Agama dapat memberi sumbangan positif bagi perkembangan sosial umat manusia apabila agama ditempatkan pada tempatnya.

Agama memberi sumbangan positif bagi masyarakat berupa pemeliharaan dan peningkatan solidaritas sosial umat manusia.

Agama juga berperan dalam pengintegrasian nilai-nilai dan norma-norma sosial

Agama juga berperan dalam pengukuhan nilai-nilai 


\section{DAFTAR PUSTAKA}

Bellah, R. N, Evolusi Agama, dalam Agama: Dalam Analisa dan Intrepretasi Sosiologis, Roland Robertson, Rajawali, Jakarta 1988

Djamari, Agama Dalam Perspektif Sosiologi, Alfabeta,, Bandung, 1993

Eisenstadt ,S.N, Tesis Mengenai Etika Protestan, Dalam Agama: Dalam Analisa dan Intrepretasi Sosiologis, Roland Robertson, Rajawali, Jakarta 1988

Pals, Daniel L., Seven Theories of Religion, Qalam, Yogyakarta, 2001

Soroush, Abdul Karim, Menggugat Otoritas dan Tradisi Agama, Mizan, Bandung, 2002

Stark, R. dan C. Y Glock : Dimensi-dimensi Keberagamaan, dalam Agama Dalam Analisa dan Intrepretasi Sosiologis, Roland Robertson, Rajawali, Jakarta 1988

Weber, Max . Etika Protestan dan Semangat Kapitalisme, Pustaka Promethea, Surabaya, 2000,

A. Musthafa, Etos Ekonomi dalam Kesalehan Agama, Resensi Buku Kesalehan Sosial, Mohammad Sobary, Seputar Indonesia, Minggu 30 Desember 2007 hal 6 